Original Article

\title{
Faktor-Faktor yang Berhubungan dengan Pemberian ASI Eksklusif di Kabupaten
} Pesawaran

\author{
Factors Associated with Exclusive Breastfeeding in Pesawaran District
}

\author{
Susan Febrica*, Sugeng Eko Irianto, Achmad Djamil \\ Prodi Magister Kesehatan Masyarakat, Fakultas Kesehatan Masyarakat, Universitas Mitra \\ Indonesia
}

(*susanfebrica1202@gmail.com)

\begin{abstract}
ABSTRAK
Tujuan penelitian yaitu untuk mengetahui faktor-faktor apa sajakah yang menyebabkan rendahnya pencapaian ASI Eksklusif di Kabupaten Pesawaran. Penelitian ini merupakan penelitian kuantitatif dengan desain Cross Sectional. Besar sampel adalah 100 orang yang merupakan ibu menyusui bayi usia 6 bulan s.d $<2$ tahun. Penelitian ini dilakukan di Kabupaten Pesawaran. Waktu pelaksanaan pada bulan Maret 2021. Analisis data yaitu uji statistik Chi Square dengan tingkat kepercayaan $95 \%(\alpha=0,05)$. Hasil penelitian yaitu responden yang tidak memberikan ASI eksklusif sebesar $42 \%$. Usia dan pekerjaan ibu secara statistic tidak terdapat hubungan yang bermakna dengan rendahnya capaian ASI ekslusif dengan nilai $p>0,05$. Variable yang memiliki hubungan yang bermakna dengan nilai $\mathrm{p}<0,05$ adalah Pendidikan ibu, dukungan suami dan penyuluhan petugas Kesehatan. Nilai OR tertinggi adalah penyuluhan oleh petugas kesehatan sebesar 6,7. Kesimpulan yaitu faktor yang paling dominan terhadap rendahnya pencapaian ASI eksklusif adalah penyuluhan oleh petugas kesehatan setelah dikontrol oleh variabel pendidikan dan dukungan suami.
\end{abstract}

Kata kunci : ASI eksklusif, penyuluhan oleh petugas kesehatan, Pendidikan Ibu, dan Dukungan Suami

\section{ABSTRACT}

The purpose of this research is to find out what factors are causing the low achievement of exclusive breastfeeding in Pesawaran Regency. This research is a quantitative research with a cross sectional design. The sample size is 100 people who are mothers breastfeeding babies aged 6 months to $<2$ years. This research was conducted in Pesawaran Regency. Implementation time in March 2021. Data analysis is Chi Square statistical test with 95\% confidence level $(\alpha=0.05)$. The result of this research is that respondents who do not give exclusive breastfeeding are $42 \%$. There was no statistically significant relationship between the mother's age and occupation with the low achievement of exclusive breastfeeding with $p$ value $>0.05$. The variables that had a significant relationship with $p$ value $<0.05$ were maternal education, husband's support and health worker counseling. The highest OR value was counseling by health workers of 6.7. The conclusion is that the most dominant factor for the low achievement of exclusive breastfeeding is counseling by health workers after being controlled by the variables of education and husband's support.

Keywords : Exclusive breastfeeding, counseling by health workers, Mother's Education, and Husband's Support https://doi.org/10.33860/jik.v15i3.506

(C) 2021 by the authors. Submitted for possible open access publication under the terms and conditions of the Creative Commons Attribution (CC BY SA) license (https://creativecommons.org/licenses/by-sa/4.0/). 


\section{PENDAHULUAN}

Pemberian ASI Eksklusif pada bayi merupakan hal yang penting dalam memenuhi kebutuhan gizi pada awal kehiduoan karena memiliki pengaruh langsung pada kualitas kesehatan dan tingkat kematian populasi secara keseluruhan ${ }^{1,2}$. ASI merupakan makanan yang dapat memenuhi kebutuhan gizi bayi karena mengandung gizi yang cukup yaitu protein, karbohidrat, lemak, vitamin, dan mineral, serta antioksidan $^{3}$. Penyakit yang umum dialami bayi seperti diare, ISPA, dan radang paru-paru dapat dicegah dengan pemberian ASI karena ASI awal mengandung zat kekebalan tubuh dari $\mathrm{ibu}^{4}$.

Pemberian ASI selama 6 bulan hingga anak berumur 2 tahun dapat menurunkan angka kesakitan dan angka kematian anak ${ }^{5}$. Angka pemberian ASI eksklusif di Indonesia pada bayi berumur 6 bulan hanya mencapai angka 30,2\% kemudian meningkat berdasarkan hasil Riskesdas 2018 menjadi 37,3\%, namun masih jauh dari target yang ditetapkan pemerintah yaitu $80 \% 6$. Keberhasilan pemberian ASI Eksklusif pada bayi dipengarahui oleh beberapa faktor yaitu umur ibu, Pendidikan, pekerjaan, status kehamilan, dukungan suami, kondisi puting susu lecet, penyuluhan oleh petugas Kesehatan, tempat dan penolong persalinan, social ekonomi, dukungan keluarga, promosi susu formula, dan adanya infeksi ${ }^{7-10}$.

Capaian ASI Ekslusif di Kabupaten Pesawaran selama tahun 2014-2019 berfluktuatif. Pada tahun 2014 bayi yang mendapatkan ASI secara eksklusif sebesar $30,19 \%$, tahun 2015 menuurn menjadi $20,85 \%$, tahun 2016 meningkat menjadi $49,76 \%$ dan pada tahun 2019 sebesar 50,48\% dan masih berada dibawah target nasional yang diharapkan yaitu $80 \%{ }^{11}$. Berdasarkan hasil prasurvei yang dilakukan oleh peneliti dari 30 orang ibu menyusui, terdapat sebanyak 17 orang ibu $(56,6 \%)$ dengan rata-rata usia pada rentang 15-25 tahun dan sebagian besar dengan tingkat pendidikan rendah yang tidak memberikan ASI eksklusif dengan alasan ibu bekerja dan tidak mendapatkan dukungan dari suami untuk memberikan ASI eksklusif.

Tujuan penelitian yaitu untuk mengetahui faktor-faktor yang berhubungan dengan pemberian ASI eksklusif di Kabupaten Pesawaran.

\section{METODE PENELITIAN}

Penelitian ini merupakan penelitian kuantitatif dengan desain Cross Sectional. Populasi dalam penelitian ini yaitu seluruh ibu menyusui bayi usia 6 bulan s.d $<2$ tahun sedangkan sampel yang diambil dalam penelitian ini yaitu sebagian dari ibu menyusui bayi usia 6 bulan s.d $<2$ tahun yang terpilih sebagai sampel. Besar sampel dihitung dengan menggunakan rumus Slovin yaitu sebanyak 100 sampel. Penelitian ini dilakukan di Kabupaten Pesawaran. Waktu pelaksanaan pada bulan Maret 2021.

Pengumpulan data primer yaitu karakteristik responden (umur, Pendidikan, pekerjaan), dukungan suami, Penyuluhan oleh petugas Kesehatan, dan Praktek ASI Eksklusif dilakukan dengan menggunakan kuesioner yang telah divalidasi dan uji reliabilitasnya.

Analisis data menggunakan Program SPSS denagn statistic uji statistik Chi Square dengan tingkat kepercayaan $95 \%(\alpha=0,05)$ dan uji regresi logistik.

\section{HASIL}

Table 1 menunjukkan bahwa responden dengan usia berisiko 21 responden $(21 \%)$, jumlah responden yang bekerja sebanyak 30 responden $(30 \%)$, responden dengan tingkat pendiidkan rendah sebanyak 39 responden (39\%), jumlah responden yang mendapat tidak dukungan suami sebanyak 57 responden (57\%), jumlah responden yang tidak mendapatkan penyuluhan sebanyak 49 responden (49\%), dan jumlah responden yang tidak memberikan ASI eksklusif di Kabupaten Pesawaran tahun 2021 sebanyak 42 responden (42\%).

Tabel 1 Karakteristik Responden dan Dukungan Petugas Kesehatan serta ASI eksklusif

\begin{tabular}{|c|c|c|}
\hline Variabel & $\mathbf{n}$ & $\%$ \\
\hline \multicolumn{3}{|l|}{ Usia } \\
\hline Berisiko & 21 & 21 \\
\hline Tidak berisiko & 79 & 79 \\
\hline \multicolumn{3}{|l|}{ Pekerjaan } \\
\hline Bekerja & 30 & 30 \\
\hline Tidak bekerja & 70 & 70 \\
\hline \multicolumn{3}{|l|}{ Pendidikan } \\
\hline Rendah & 39 & 39 \\
\hline Tinggi & 61 & 61 \\
\hline \multicolumn{3}{|l|}{ Dukungan Suami } \\
\hline Tidak mendukung & 57 & 57 \\
\hline mendukung & 43 & 43 \\
\hline \multicolumn{3}{|c|}{ Penyuluhan oleh petugas Kesehatan } \\
\hline Tidak & 49 & 49 \\
\hline $\mathrm{Ya}$ & 51 & 51 \\
\hline
\end{tabular}




\begin{tabular}{lll}
\hline \multicolumn{1}{c}{ Variabel } & n & \% \\
\hline ASI eksklusif & & \\
Tidak ASI eksklusif & 42 & 42 \\
ASI eksklusif & 58 & 58 \\
\hline
\end{tabular}

Table 2 menunjukkan bahwa usia dan pekerjaan ibu secara statistic tidak terdapat hubungan yang bermakna dengan rendahnya capaian ASI ekslusif dengan nilai $\mathrm{p}>0,05$. Variable yang memiliki hubungan yang bermakna dengan nilai $\mathrm{p}<0,05$ adalah Pendidikan ibu, dukungan suami dan penyuluhan petugas Kesehatan. Nilai OR terbesar adalah peyuluhan oleh petugas Kesehatan yaitu OR 6,7 yang artinya ibu yang tidak mendapatkan penyuluhan oleh petugas kesehatan memiliki risiko 6,7 kali lebih tinggi untuk tidak memberikan ASI ekslusif ibu yang mendapatkan penyuluhan oleh petugas kesehatan.

Tabel 3 menunjukkan bahwa faktor yang paling dominan terhadap rendahnya pencapaian ASI eksklusif adalah penyuluhan oleh petugas kesehatan setelah dikontrol oleh variabel pendidikan dan dukungan suami

Tabel 2 Uji Bivariat terhadap Pemberian ASI Eksklusif

\begin{tabular}{|c|c|c|c|c|c|c|c|}
\hline \multirow{3}{*}{ Variabel } & \multicolumn{4}{|c|}{ Pemberian ASI Ekslusif } & \multirow{3}{*}{ Total } & \multirow{3}{*}{ P-Value } & \multirow{3}{*}{$\begin{array}{c}\text { OR } \\
(95 \% \text { CI })\end{array}$} \\
\hline & \multicolumn{2}{|c|}{ Tidak ASI Eksklusif } & \multicolumn{2}{|c|}{ ASI Eksklusif } & & & \\
\hline & $\mathbf{n}$ & $\%$ & $\mathbf{n}$ & $\%$ & & & \\
\hline \multicolumn{8}{|l|}{ Usia Ibu } \\
\hline Berisiko & 10 & 47,6 & 11 & 52,4 & 21 & \multirow[t]{2}{*}{0,735} & \multirow[t]{2}{*}{ NA } \\
\hline Tidak Berisiko & 32 & 40,5 & 47 & 59,5 & 79 & & \\
\hline \multicolumn{8}{|l|}{ Pekerjaan Ibu } \\
\hline Bekerja & 13 & 43,3 & 17 & 56,7 & 30 & \multirow[t]{2}{*}{1,000} & \multirow[t]{2}{*}{ NA } \\
\hline Tidak Bekerja & 29 & 41,4 & 41 & 58,6 & 70 & & \\
\hline \multicolumn{8}{|l|}{ Pendidikan Ibu } \\
\hline Rendah & 22 & 56,4 & 17 & 43,6 & 39 & \multirow[t]{2}{*}{0,033} & 2,6 \\
\hline Tinggi & 20 & 32,8 & 41 & 67,2 & 61 & & $(1.1-6,0)$ \\
\hline \multicolumn{8}{|l|}{ Dukungan Suami } \\
\hline Tidak mendukung & 29 & 52,7 & 26 & 47,3 & 55 & \multirow[t]{2}{*}{0,028} & 2,7 \\
\hline Mendukung & 13 & 28,9 & 32 & 71,1 & 45 & & $(1.1-6,3)$ \\
\hline \multicolumn{8}{|c|}{ Penyuluhan Petugas Kesehatan } \\
\hline Tidak berikan & 31 & 64,6 & 17 & 35,4 & 48 & \multirow[t]{2}{*}{0,000} & 6,7 \\
\hline Ya diberikan & 11 & 21,2 & 41 & 78,8 & 52 & & $(2,7-16,5)$ \\
\hline
\end{tabular}

Tabel 3 Uji Multivariate

\begin{tabular}{ccccc}
\hline Variabel & \multirow{2}{*}{ Sig } & \multirow{2}{*}{ Exp (B) } & 95\% CI \\
\cline { 4 - 5 } & & 4,078 & 1,482 & Upper \\
\hline Pendidikan & 0,006 & 2,984 & 0,891 & 11,218 \\
Dukungan suami & 0,084 & 7,702 & 2,841 & 6,163 \\
Penyuluhan & 0,000 & & 20,877 \\
\hline
\end{tabular}

\section{PEMBAHASAN}

\section{Usia Ibu}

Hasil analisis hubungan antara usia ibu dengan rendahnya capaian ASI ekslusif di Kabupaten pesawaran diperoleh data bahwa dari 21 responden dengan usia berisiko didapatkan sebanyak 10 responden $(47,6 \%)$ yang tidak memberikan ASI ekslusif dan 11 responden ( $52,4 \%$ ) yang memberikan ASI ekslusif dan hasil uji statistik didapatkan nilai $\mathrm{P}$-value $=0,735(\mathrm{P}>0,05)$ yang artinya secara statistik tidak terdapat hubungan yang bermakna antara usia ibu dengan rendahnya capaian ASI ekslusif di Kabupaten Pesawaran tahun 2021.

Penelitian lain menunjukkan bahwa ada hubungan yang signifikan antara umur ibu, dengan perilaku pemberian ASI eksklusif di Desa Candimas Kecamatan Natar dan semakin cukup umur maka tingkat kematangan dan kekuatan seseorang akan lebih matang dalam berpikir dan bekerja ${ }^{12}$. Dalam kurun waktu reproduksi sehat dikenal usia aman untuk kehamilan, persalinan, dan menyusui adalah 20-35 tahun dan wanita yang lebih tua $(\geq 40$ tahun) memiliki peningkatan kemungkinan untuk preeklamsia ringan, gawat janin, dan pertumbuhan janin yang buruk serta Usia ibu muda ( $\leq 19$ tahun) dikaitkan dengan peningkatan kemungkinan preeklamsia ringan (kenaikan 60\% untuk usia 15-19 tahun, peningkatan peluang 2,5 kali lipat untuk usia 
11-14 tahun $)^{13}$. Penelitian lainnya menunjukkan bahwa tingkat menyusui tetap rendah secara tidak proporsional di antara ibu remaja dimana terdapat $60 \%$ wanita berusia kurang dari 20 tahun memulai menyusui, dibandingkan dengan hampir $80 \%$ wanita berusia di atas 30 tahun. Selain itu, hanya $20 \%$ wanita muda yang masih menyusui pada 6 bulan dibandingkan dengan $50 \%$ wanita yang lebih tua ${ }^{14}$.

\section{Pekerjaan}

Hasil analisis hubungan antara pekerjaan ibu dengan rendahnya capaian ASI ekslusif di Kabupaten pesawaran diperoleh data bahwa dari 30 responden yang bekerja didapatkan sebanyak 13 responden $(43,3 \%)$ yang tidak memberikan ASI ekslusif dan 17 responden $(56,7 \%)$ yang memberikan ASI ekslusif. Hasil uji statistik didapatkan nilai Pvalue $=1,000(\mathrm{P}>0,05)$ yang artinya secara statistik tidak terdapat hubungan yang bermakna antara pekerjaan ibu dengan rendahnya capaian ASI ekslusif di Kabupaten Pesawaran tahun 2021.

Pemberian ASI yang dikombinasikan dengan pemberian susu botol kenyataannya tidak dapat dihindari karena ibu-ibu bekerja diluar rumah, sedangkan ditempat kerja tidak terdapat fasilitas untuk memberikan ASI dan penampungan bayi ${ }^{15}$. Penelitian Erinka Pricornia Mudaharimi (2021) menunjukkan bahwa ibu yang bekerja mengalami beberapa masalah, seperti kelelahan kerja dan stres yang memengaruhi produksi ASI dan adanya persepsi bahwa ASI yang tidak mencukupi dapat memengaruh keberhasilan pemberian $\mathrm{ASI}^{16}$.

\section{Pendidikan Ibu}

Hasil analisis hubungan antara tingkat pendidikan ibu dengan rendahnya capaian ASI ekslusif di Kabupaten pesawaran diperoleh data bahwa dari 39 responden dengan tingkat pendidikan rendah didapatkan sebanyak 22 responden $(56,4 \%)$ yang tidak memberikan ASI ekslusif dan 17 responden ( 43,6 \% ) yang memberikan ASI ekslusif. Hasil uji statistik didapatkan nilai $\mathrm{P}$-value $=0,033(\mathrm{P}<0,05)$ yang artinya secara statistik terdapat hubungan yang bermakna antara tingkat pendiidkan ibu dengan rendahnya capaian ASI ekslusif di Kabupaten Pesawaran tahun 2021. Berdasarkan hasil analisis juga didapatkan nilai OR 2,6 yang artinya ibu dengan tingkat pendidikan rendah memiliki risiko 2,6 kali lebih tinggi untuk tidak memberikan ASI ekslusif ibu dengan tingkat pendiidkan tinggi.

Hasil penelitian Ratna Yuliawati dkk (2018) menunjukkan bahwa tingkat pendidikan ibu berpengaruh positif terhadap praktik pemberian ASI eksklusif di Indonesia dimana semakin tinggi tingkat pendidikan ibu, pengetahuan semakin baik dan lebih mudah menerima suatu ide yang baru ${ }^{17}$. Kemudian, pendidikan, pengetahuan, dan pengalaman ibu adalah faktor predisposisi yang berpengaruh positif terhadap keberhasilan ASI eksklusif $^{18}$. Penelitian Agung Dwi Laksano dkk (2021) menunjukkan bahwa ibu yang tamat SD berpeluang 1,167 kali lebih besar untuk melakukan ASI eksklusif dibandingkan dengan ibu yang tidak pernah sekolah. Selain itu, mereka yang tamat SMP memiliki kemungkinan 1,203 kali untuk memberikan ASI eksklusif dibandingkan dengan ibu yang tidak memiliki catatan pendidikan. Sedangkan ibu yang tamat SLTA berpeluang 1,177 kali lebih besar untuk melakukan pemberian ASI eksklusif dibandingkan dengan ibu yang tidak memiliki catatan pendidikan. Ibu yang tamat perguruan tinggi memiliki kemungkinan 1,203 kali lebih besar untuk melakukan pemberian ASI eksklusif dibandingkan dengan ibu yang tidak pernah bersekolah. Variabel lain juga menjadi prediktor yang mempengaruhi pemberian ASI eksklusif, seperti usia ibu, status pekerjaan ibu, usia anak, dan tempat tinggal ${ }^{19}$.

\section{Dukungan Suami}

Hasil analisis hubungan antara dukungan suami dengan rendahnya capaian ASI ekslusif di Kabupaten pesawaran diperoleh data bahwa dari 55 responden yang suaminya tidak mendukung didapatkan sebanyak 29 responden $(52,7 \%)$ yang tidak memberikan ASI ekslusif dan 26 responden ( 47,3\%) yang memberikan ASI ekslusif. Hasil uji statistik didapatkan nilai $\mathrm{P}$-value $=0,028(\mathrm{P}<0,05)$ yang artinya secara statistik terdapat hubungan yang bermakna antara dukungan suami dengan rendahnya capaian ASI ekslusif di Kabupaten Pesawaran tahun 2021. Berdasarkan hasil analisis juga didapatkan nilai OR 2,7 yang artinya ibu yang tidak mendapatkan dukungan suami memiliki risiko 2,7 kali lebih tinggi untuk tidak memberikan ASI ekslusif ibu yang mendapatkan dukungan suami.

Suciati, Qudriani, dan Baroroh dkk (2015) menunjukkan bahwa peran suami terhadap pemberian ASI eksklusif dapat 
dipengaruhi oleh pengetahuan suami terhadap hal-hal yang berhubungan dengan pemberian ASI eksklusif. suami yang memiliki pengetahuan baik maka memiliki peluang lebih sebanyak 9,4 kali untuk memberikan dukungan kepada istrinya dalam pemberian ASI eksklusif $^{20}$. Dukungan untuk keberhasilan proses menyusui berasal dari beberapa pihak, diantaranya adalah keluarga, kelompok pendukung ASI, masyarakat, dan Pemerintah ${ }^{21}$.

Ibu yang mendapatkan dukungan suami lebih besar peluangnya untuk memberikan ASI eksklusif dibandingkan dengan ibu yang tidak mendapatkan dukungan suami ${ }^{22}$. Dukungan penuh seorang suami kepada istrinya dalam proses menyusui bayinya meningkatkan keberhasilan menyusui ASI secara eksklusif. Peran breastfeeding father menjadi hal yang wajib dilakukan oleh ayah agar mendukung pemberian ASI eksklusif, sehingga proses menyusui secara eksklusif oleh ibu dapat berjalan dengan sukses ${ }^{22}$.

\section{Penyuluhan Petugas Kesehatan}

Hasil analisis hubungan antara penyuluhan petugas kesehatan dengan rendahnya capaian ASI ekslusif di Kabupaten pesawaran diperoleh data bahwa dari 48 responden yang suaminya tidak mendukung didapatkan sebanyak 31 responden $(64,6 \%)$ yang tidak memberikan ASI ekslusif dan 17 responden ( 35,4\%) yang memberikan ASI ekslusif. Hasil uji statistik didapatkan nilai $\mathrm{P}$-value $=0,000(\mathrm{P}<0,05)$ yang artinya secara statistik terdapat hubungan yang bermakna antara penyuluhan oleh petugas kesehatan dengan rendahnya capaian ASI ekslusif di Kabupaten Pesawaran tahun 2021. Berdasarkan hasil analisis juga didapatkan nilai OR 6,7 yang artinya ibu yang tidak mendapatkan penyuluhan oleh petugas kesehatan memiliki risiko 6,7 kali lebih tinggi untuk tidak memberikan ASI ekslusif ibu yang mendapatkan penyuluhan oleh petugas kesehatan.

Hasil penelitian lainnya menunjukkan terdapat pengaruh peran petugas kesehatan dan Baper Asiek terhadap perilaku ibu dalam pemberian ASI eksklusif dengan $p$ value peran petugas kesehatan $=0,022$ dan $\mathrm{p}$ value Baper Asiek $=0,000{ }^{23}$. Petugas kesehatan (dokter, bidan, ahli gizi) harus senantiasa meningkatkan pengetahuan dan kompetensi untuk mendukung upaya peningkatan dan pemberian ASI eksklusif. Keterlibatan peranan petugas kesehatan dalam aspek social sangat penting dalam melindungi, meningkatkan, dan mendukung usaha menyusui para ibu yang memiliki anak 0-2 tahun ${ }^{24}$.

\section{KESIMPULAN DAN SARAN}

Variabel dominan yang berhubungan dengan rendahnya capaian ASI Ekslusif di Kabupaten Pesawaran tahun 2021 adalah penyuluhan oleh petugas kesehatan setelah dikontrol oleh variabel tingkat pendidikan ibu dan dukungan suami. Diharapkan dapat lebih memberikan sosialisasi dan penyuluhan akan pentingnya ASI Ekslusif bagi tumbuh kembang bayi dan memberikan konseling pra persalinan kepada ibu hamil.

\section{DAFTAR PUSTAKA}

1. Kramer MS, Kakuma R. Optimal duration of exclusive breastfeeding. Cochrane Database Syst Rev. 2012 Aug 15;15(8):CD003517.

2. WHO. Effect of breastfeeding on infant and child mortality due to infectious diseases in less developed countries: a pooled analysis. The Lancet. 2000 Feb;355(9202):451-5.

3. Martin CR, Ling P-R, Blackburn GL. Review of Infant Feeding: Key Features of Breast Milk and Infant Formula. Nutrients. 2016 May 11;8(5):279.

4. Bakar A, Rohma EF, Kurnia ID, Qomariah SN. Exclusive Breastfeeding Associated with the Reduction of Acute Respiratory Tract Infections in Toddlers with High-Risk Factors. Jurnal Ners. 2018;13(2):213-8.

5. Lamberti LM, Zakarija-Grković I, Fischer Walker CL, Theodoratou E, Nair H, Campbell $\mathrm{H}$, et al. Breastfeeding for reducing the risk of pneumonia morbidity and mortality in children under two: a systematic literature review and meta-analysis. BMC Public Health. 2013 Sep 17;13(Suppl 3):S18.

6. Kemenkes RI. Hasil Riset Kesehatan Dasar Tahun 2018. Jakarta: Kementrian Kesehatan RI; 2019.

7. Kaski K, Kvist LJ. Deep breast pain during lactation: a case-control study in Sweden investigating the role of Candida albicans. International Breastfeeding Journal. 2018 Jun 7;13(1):21.

8. Pusporini AD, Pangestuti DR, Rahfiludin MZ. Faktor-Faktor yang Berhubungan dengan Praktik ASI Eksklusif di Daerah Pertanian Kabupaten Semarang (Studi pada Ibu yang Memiliki Bayi Usia 0-6 Bulan). MEDIA KESEHATAN MASYARAKAT INDONESIA. 2021 Apr 1;20(2):83-90.

9. Raj JF, Fara YD, Mayasari AT, Abdullah A. Faktor yang mempengaruhi pemberian ASI eksklusif. Wellness And Healthy Magazine. 2020 Aug 29;2(2):283-91. 
10. Yumni FL, Wahyuni CT. Hubungan Promosi Iklan Susu Formula Dengan Pemberian ASI Eksklusif Di Desa Pandanarum Kecamatan Pacet Kabupaten Mojokerto. Jurnal Keperawatan Muhammadiyah. 2018 Dec 20;3(2):95-100.

11. Dinas Kesehatan Kabupaten Pesawaran. Profil Kesehatan Kabupaten Pesawaran. Pesawaran: Dinas Kesehatan Kabupaten Pesawaran; 2010.

12. Nurhayati N, Ilyas H, Murhan A. FaktorFaktor Yang Berhubungan Dengan Pemberian Asi Eksklusif Di Desa Candimas. Jurnal Ilmiah Keperawatan Sai Betik. 2017 Sep 15;11(1):86-95.

13. Cavazos-Rehg PA, Krauss MJ, Spitznagel EL, Bommarito K, Madden T, Olsen MA, et al. Maternal age and risk of labor and delivery complications. Matern Child Health J. 2015 Jun;19(6):1202-11.

14. Sipsma HL, Magriples U, Divney A, Gordon D, Gabzdyl E, Kershaw T. Breastfeeding behavior among adolescents: Initiation, duration, and exclusivity. J Adolesc Health. 2013 Sep;53(3):394-400.

15. Manuaba. Ilmu Kebidanan, Penyakit Kandungan \& Keluarga Berencana untuk Pendidikan Bidan. Jakarta: EGC; 2012.

16. Mudaharimbi EP. Self-Efficacy of Primigravida Working Mothers in the Success of Breastfeeding. Jurnal Promkes: The Indonesian Journal of Health Promotion and Health Education. 2021 Mar 30;9(1):28-35.

17. Yuliawati R, Kurniasari L, Maryam S. Hubungan antara pendidikan dan dukungan keluarga dengan kegagalan asi eksklusif. JHeS (Journal of Health Studies). 2018 Sep 12;2(2):73-80.

18. Fikawati S, Syafiq A. Penyebab Keberhasilan dan Kegagalan Praktik Pemberian ASI Eksklusif. Kesmas: Jurnal Kesehatan Masyarakat Nasional (National Public Health Journal). 2009 Dec 1;4(3):120-31.

19. Laksono AD, Wulandari RD, Ibad M, Kusrini I. The effects of mother's education on achieving exclusive breastfeeding in Indonesia. BMC Public Health. 2021 Jan 6;21(1):1-14.

20. Suciati NA, Qudriani M, Baroroh U. Hubungan antara tingkat pengetahuan suami mengenai ASI eksklusif dengan penerapan breast-feeding father di kelurahan Pesurungan Lor Kecamatan Margadana tahun 201. Siklus: Journal Research Midwifery Politeknik Tegal. 2016 Mar 2;4(2):91-3.

21. Syamsiah S. Tingkat Pengetahuan Suami Mengenai ASI Eksklusif dan Hubungannya dengan Penerapan Breastfeeding Father. Jurnal Kesehatan Prima. 2011;3(1):1-13.

22. Kusumayanti N, Nindya TS. Association of Husband Support and Exclusive Breastfeeding in Rural Area. Media Gizi Indonesia. 2017;12(2):98-106.

23. Cahyono A, Ulfah M, Handayani RN. Pengaruh Peran Petugas Kesehatan dan Bapak Peduli ASI Eksklusif (Baper Asiek) Terhadap Perilaku Ibu dalam Pemberian ASI Eksklusif di Wilayah Kerja Puskesmas Rembang Kabupaten Purbalingga. Jurnal Kebidanan dan Keperawatan 'Aisyiyah. 2020;16(1):6786.

24. Dwiani A, Destriatania S, Mutahar R. Analysis of the Factors Relating to The Granting of Exclusive Breastfeeding at Dempo Health Centres Palembang and Simpang Timbangan Health Centres Ogan Ilir 2012. Jurnal Ilmu Kesehatan Masyarakat. 2014;5(1):9-18. 